\title{
Endocrine variant of ductal carcinoma in situ of breast: ultrastructural and light microscopical study
}

\author{
M T ASHWORTH, M T HAQQANI \\ From the Department of Histopathology, Walton Hospital, Liverpool
}

SUMMARY The ultrastructural and light microscopic presentation of the recently described entity of the in situ endocrine variant of ductal carcinoma of breast are presented.

Argyrophilic cells in breast ducts and ductules have been described by several workers in normal and abnormal breasts. ${ }^{1-4}$ Carcinoid tumours of the breast were subsequently reported on the basis of argyrophilia and dense core granules ultrastructurally. ${ }^{5}$ More recently, neurone specific enolase positivity has contributed to the diagnosis. Some workers have taken a sceptical view of the endocrine nature of such cells, stating that Grimelius staining and dense core granules are not specific for endocrine cells. ${ }^{67}$ Azzopardi et al ${ }^{8}$ concluded that argyrophil carcinomas of the breast should be regarded as a distinctive group of tumours. In a recent study ${ }^{9}$ of endocrine tumours they found that a high proportion of in situ ductal carcinomas show an organoid pattern, with distinctive structural and cytological features,

Accepted for publication 17 June 1986 neurone specific enolase positivity, and ultrastructural dense core granules. They applied the term endocrine variant of ductal carcinoma in situ to these tumours.

\section{Case histories}

\section{CASE 1}

A 73 year old woman presented in April 1985 with a tender lump in the left breast, which she had noticed two weeks previously. Six years ago she had felt a lump in the upper quadrant of the same breast that had settled down before she was examined by the surgeon. A xerogram performed at the same time noted duct ectasia and collagenosis without any other abnormality. Her medication comprised digoxin ( $250 \mathrm{mg}$ at night). She smoked 10 cigarettes daily and did not drink alcohol.

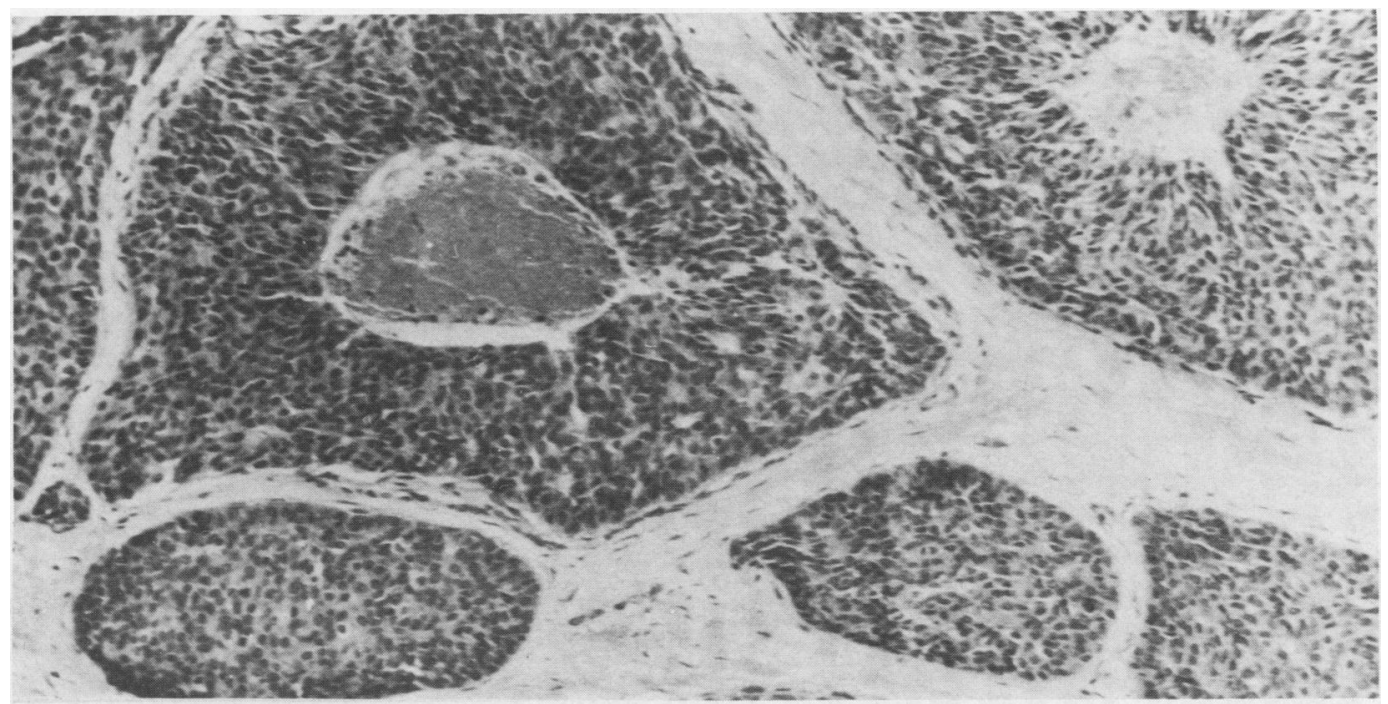

Fig 1 Solid lobules of uniform cells with round or oval nuclei. Individual cells are polygonal tending to spindle shape, with palisaded arrangement towards periphery of lobules. (Haematoxylin and eosin.) $\times 250$. 


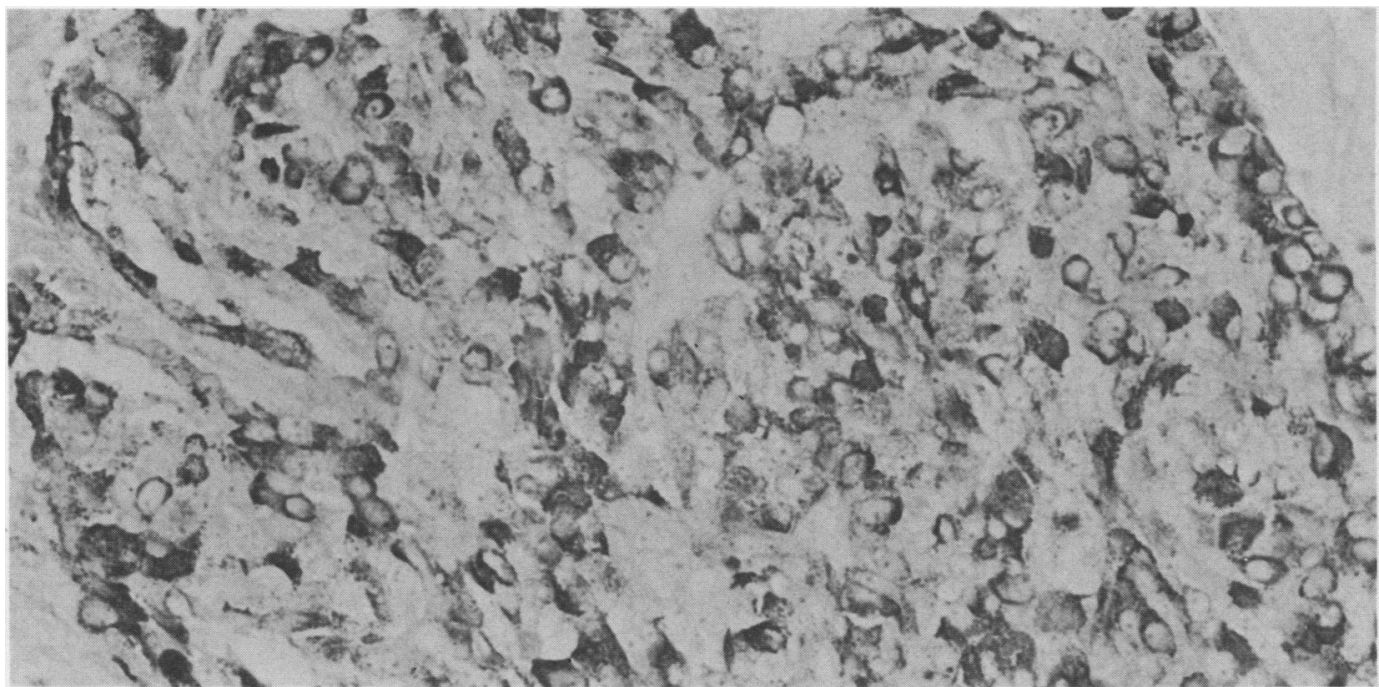

Fig 2 Strong argyrophilia as seen with Grimelius stain. Virtually all cells show Grimelius positive granules.

(Grimelius.) $\times 500$.

Examination showed that the right breast was normal. There was a rounded mobile swelling measuring $5 \mathrm{~cm}$ in diameter in the left breast situated behind the nipple and without attachment to the skin or deeper tissues. No nipple discharge was present and the nipple was normal. There were no palpable axillary or supraclavicular lymph nodes. Physical examination yielded otherwise normal results. Biochemical and haematological indices were normal. Attempted aspiration was unsuccessful. The swelling was removed via a transverse incision with insertion of a drain. Postoperative recovery was uneventful and wound healing unremarkable. Six months postoperatively she remained well with no evidence of recurrence.

The excised specimen consisted of a lobulated piece of grey soft tissue measuring $5 \times 5 \times 3 \mathrm{~cm}$ and seemed to be circumscribed. The cut surface exhibited small yellow streaks of necrosis. Histologically the tumour was composed of solid lobules of relatively uniform cells with pale finely granular eosinophilic

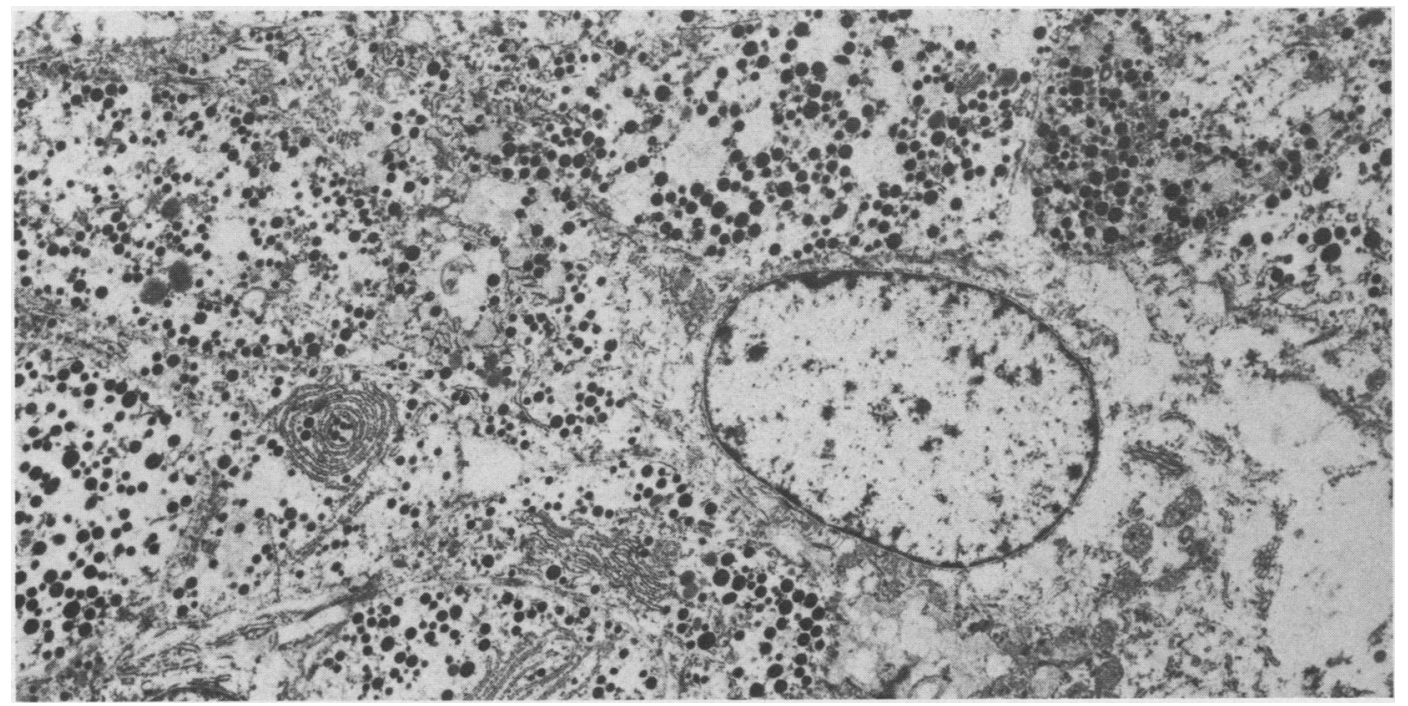

Fig 3 Characteristic ultrastructural dense core granules. (Uranyl acetate and lead citrate.) $\times 7800$. 


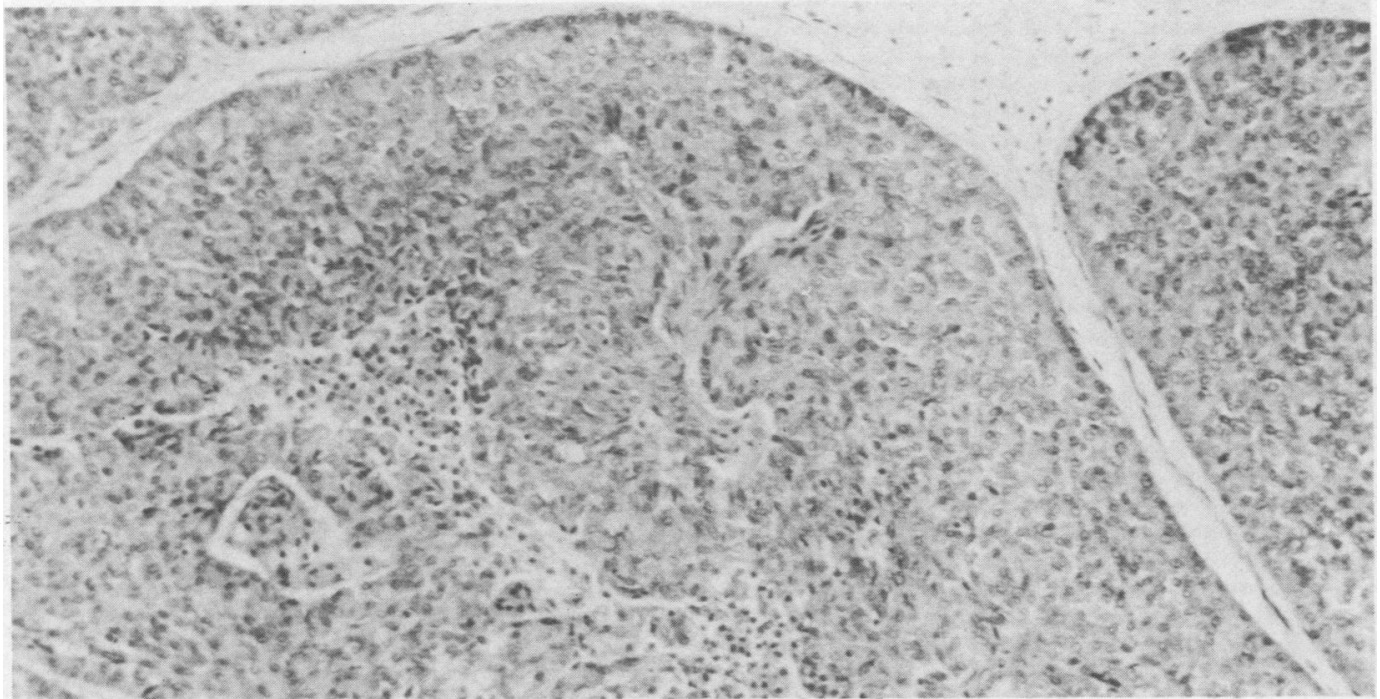

Fig 4 Pseudoglandular structures and stromal inclusions in solid groups of cells (Haematoxylin and eosin.) $\times 250$.

cytoplasm; vesicular, round, or oval nuclei; and inconspicuous nucleoli. The individual cells were polygonal, sometimes tending to spindle shape instead, but those at the periphery of the lobules and around stromal inclusions were columnar with a distinct palisaded arrangement (fig 1). There were small or large solid areas of trabecular arrangement with occasional pseudorosettes. Stromal inclusions consisting of hyaline tissue and small blood vessels were prominent, and in many areas could be seen to be contiguous with the surrounding stroma, which showed evidence of old and recent haemorrhage. Fibrosis and inflammatory cell infiltration were inconspicuous, and although pushing margins of tumour growth were seen, no convincing evidence of invasion could be identified. Scattered cells contained periodic acid Schiff positive diastase resistant material in their cytoplasm, particularly the peripheral palisaded cells. Most of the cells showed a strong argyrophilia with fine granular black staining of their cytoplasm by the Grimelius silver method (fig 2).

Ultrastructurally the tumour cells contained round

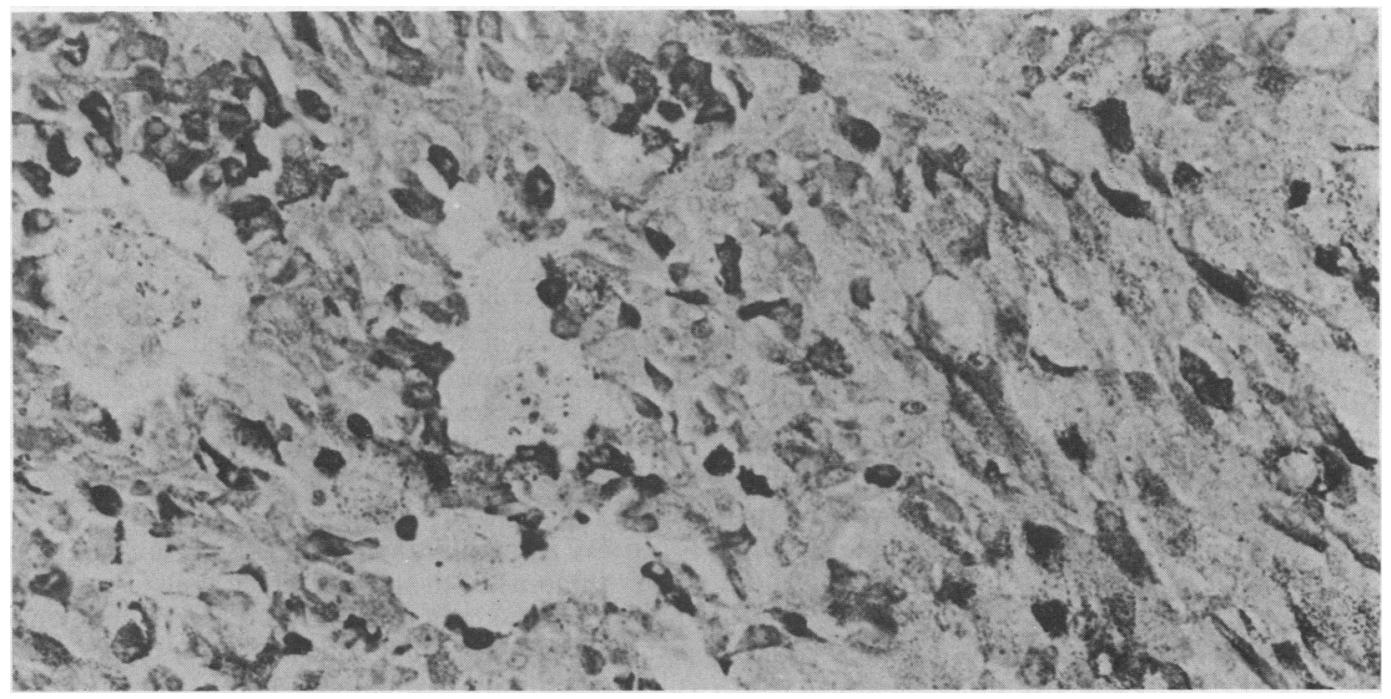

Fig 5 Grimelius positive cells in lobules (Grimelius.) $\times 500$. 


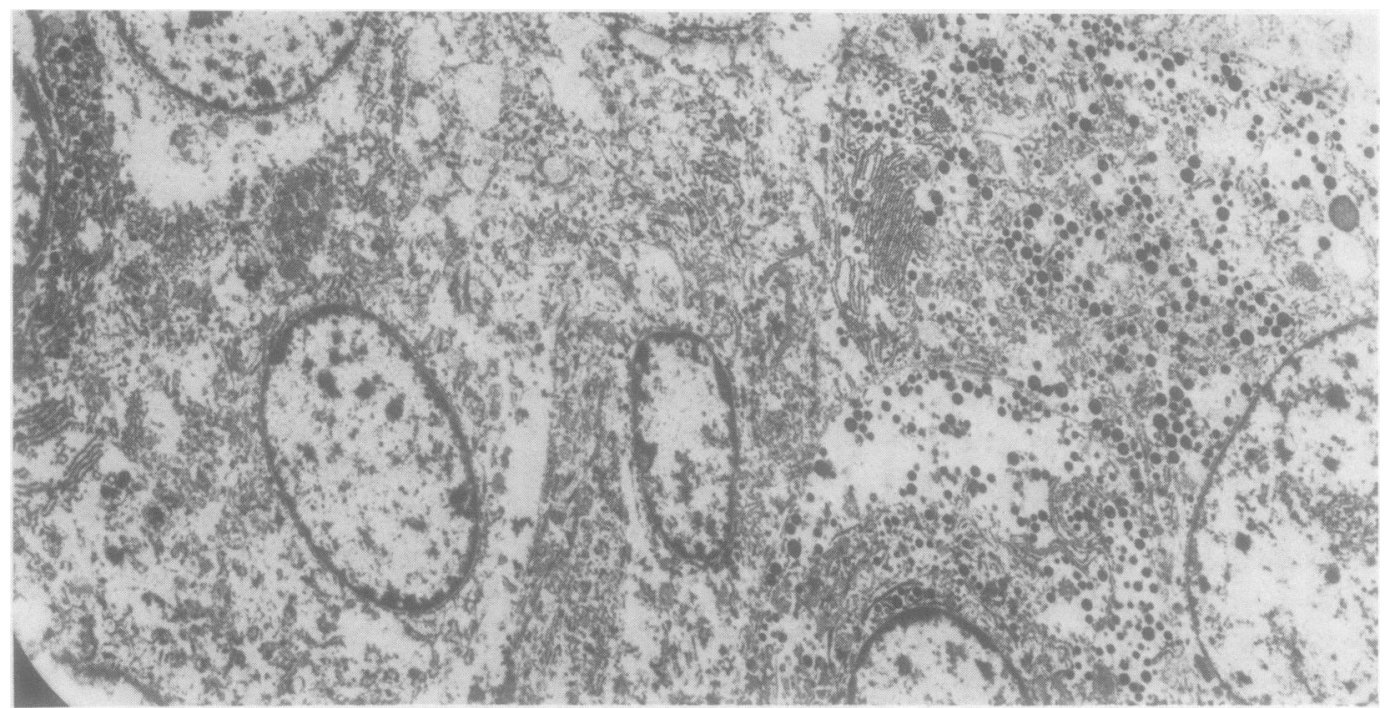

Fig 6 Ultrastructural dense core granules. (Uranyl acetate and lead citrate.) $\times 7800$.

dense core granules of a mean diameter of $360 \mathrm{~nm}$. The number per cell varied from a few scattered granules to numerous granules filling the cytoplasm (fig 3). Abundant rough endoplasmic reticulum was present, and there was a prominent Golgi body in many of the cells. Some of the cells, in addition to dense core granules, also contained mucin vacuoles, although these were not a prominent feature.

The organoid pattern, strong argyrophilia seen with the Grimelius stain, and the ultrastructural dense core granules enabled us to diagnose endocrine variant of ductal carcinoma in situ.

\section{CASE 2}

A 72 year old woman presented with bloody painful discharge from the right nipple, which she had had for three weeks. She had systemic hypertension, which was controlled with timolol (10 $\mathrm{mg}$ twice daily) and bendrofluazide ( $2.5 \mathrm{mg}$ daily).

Physical examination showed a firm tender lump measuring about $6 \mathrm{~cm}$ in diameter in the lower outer quadrant of the right breast, with skin tethering and nipple retraction. The left breast was grossly normal and general physical examination was unremarkable. Biochemical and haematological indices were normal. Right simple mastectomy with axillary clearance was performed. Postoperatively there was prolonged serous discharge from the surgical wound that eventually healed fully. The patient remained alive and well without evidence of recurrent or metastatic disease three months later.

The resected specimen consisted of a breast measuring $22 \times 17 \times 7.5 \mathrm{~cm}$ with attached axillary fat. Deep within the tissue was a nodular circumscribed grey tumour measuring $4 \times 3.3 \times 3 \mathrm{~cm}$, which had not spread to skin, nipple, or deeper tissue. The surrounding breast tissue contained dilated ducts.

Histologically the tumour was similar to that described in case 1 (fig 4), with the exception tha many of the tumour units showed polypoid projections into cystic spaces, some covered wi画 ductal epithelium. There were also areas of cont ventional ductal carcinoma in situ with a cribriform $\overline{0}$ pattern. The histological changes not only were $\stackrel{\circ}{\circ}$ present in the main tumour mass but also in ducts of $\mathbb{Q}$ surrounding breast, including the large ducts beneath $\overrightarrow{\vec{\theta}}$ the nipple. Staining by the Grimelius method showed strong argyrophilia in most of the tumour cells (fig 5). No staining was seen in the areas of conventional ductal carcinoma in situ. Ultrastructurally the cells contained moderate numbers of dense core granuls (fig 6).

\section{Discussion}

Volger $^{1}$ in 1947 found argyrophilic cells in breast 옥 ducts of one of 18 specimens studied. Other workers have failed to find argyrophil cells in normal breast or benign breast lesions. ${ }^{23}$ A recent report, ${ }^{4}$ however, $N$ has described argyrophilic and chromogranin reactive endocrine cells in breast ducts and ductules in three of 27 cases of normal breast tissue.

In 1977 Cubilla and Woodruff ${ }^{5}$ reported 10 primary tumours of the breast, which they termed carci- 0 noids. The tumours had an organoid appearance, $\mathbb{\Phi}$ exhibited argyrophilia, and, in three cases examined $\stackrel{?}{+}$ ultrastructurally, contained dense core granules. $T$ Several case reports followed, ${ }^{1011}$ including an 
argentaffin carcinoid reported by Devitt, ${ }^{12}$ although its validity is doubtful Taxy et $a l^{6}$ reported a further case, but in addition examined 21 "ordinary" carcinomas of the breast and found focal argyrophilia in 11 (an incidence of $52 \%$ ). They took a sceptical view of the endocrine nature of such cells, stating that Grimelius staining was not specific for endocrine cells and that dense core granules described in these cells may have been lysosomes or mucin vacuoles. They concluded that, "some breast cancers may focally exhibit a carcinoid-like differentiation." Anderson et al ${ }^{7}$ doubted that all three features-that is, dense core granules, neurone specific enolase, and Grimelius positivity were specific for endocrine cells in the breast.

The high percentage of argyrophilia in conventional breast carcinomas found by Taxy et al has not been found by other workers. Azzopardi et al $^{8}$ found argyrophilia in $4.5 \%$ of 67 invasive breast carcinomas. Partanen and Syrjanen ${ }^{2}$ reported a figure of $3.3 \%$ for 90 adenocarcinomas and Fetisof et $\mathrm{al}^{3}$ reported an incidence of $4.8 \%$ in 92 carcinomas.

Azzopardi et $^{\mathbf{8}} \mathrm{l}^{8}$ described 14 so called "carcinoid" tumours of the breast, which had been tentatively selected on their histological and cytological appearance and subsequently confirmed by Grimelius staining. Four of these 14 tumours $(28.5 \%)$ were the argyrophil type of ductal carcinoma in situ, five $(35 \cdot 7 \%)$ invasive ductal carcinoma, one $(7 \cdot 1 \%)$ invasive lobular carcinoma and the others were complex types. They concluded that "argyrophil carcinomas" of the breast should be regarded as forming a reasonably distinctive and relatively small group of tumours. As the so called "carcinoid tumour" had been difficult to define in the breast in a more recent study ${ }^{9}$ the authors studied 30 consecutive cases of in situ carcinoma of the breast in an attempt to clarify the complex problems entailed. Seven of the 30 cases $(23.3 \%)$ were considered to be the entity of endocrine variant of ductal carcinoma in situ identified by organoid pattern, structural and cytological characteristics, argyrophilia, and ultrastructurally, by dense core granules. They regarded it as a variant of the solid type of ductal carcinoma in situ, arising by divergent differentiation from ductal epithelium. Our two cases represent further examples of this distinctive newly recognised entity.

We are grateful to Professor J G Azzopardi for his help with the diagnosis of the first case and his general helpful advice. We thank consultant surgeons $\mathrm{Mr}$ B Haggart and Mr D Sykes for allowing us to publish details of their patients. We also thank Mr W Fellows for his help with electron microscopy and Mrs Celia Wallace for typing.

\section{References}

1 Volger E. Über das basilare Helle Zellen Organ der menschilichen Brustdrüse. Klin Med (Musk) 1947;2:159-68.

2 Partanen S, Syrjänen K. Argyrophilic cells in carcinoma of the female breast. Virchow Arch (Pathol Anat) 1981;391:45-51.

3 Fetissof F, Dubois MP, et al. Argyrophilic cells in mammary carcinoma. Hum Pathol 1983;14(2):127-34.

4 Bussolati G, Gugliotta P, Sapina A, Eusebi V, Lloyd RV. Chromogranin-reactive endocrine cells in argyrophilic carcinomas ("carcinoids") and normal tissue of the breast. Am J Pathol 1985;120(2):186-92.

5 Cubilla Al, Woodruff JM. Primary carcinoid tumour of the breast: a report of eight patients. Am J Surg Pathol 1977;4:283-92.

6 Taxy JB, Tischler AS, Insalaco SJ, Battifora H. "Carcinoid" tumours of the breast-a variant of conventional breast cancer? Hum Pathol 1981;12(2):170-79.

7 Anderson TJ, Battersby S, Ferguson DJP. Argyrophilic and endocrine cells in breast cancer. Histopathology 1985;9: 1247-9.

8 Azzopardi JG, Muretto P, Goddeeris P, Eusebi V, Lauweryns JM. "Carcinoid" tumours of the breast: the morphological spectrum of argyrophil carcinomas.. Histopathology 1982;6: 549-69.

9 Cross AS, Azzopardi JG, Krausz T, Van Noorden S, Polak JM. A morphological and immunocytochemical study of a distinctive variant of ductal carcinoma in-situ of the breast. Histopathology 1985;9:21-37.

10 Kaneko H, Hojo H, Ishikawa S, Yamanouchi H, Sumida T, Saito R. Norepinephrine-producing tumours of bilateral breasts: a case report. Cancer 1978;41:2002-7.

11 Fisher ER, Palekar AS, NSABP collaborators. Solid and mucinous varieties of so-called mammary carcinoid tumours. Am J Clin Pathol 1979;72:909-16.

12 Devitt PG. Carcinoid tumour of the breast. Br Med J 1978;II:327.

Requests for reprints to: Dr M T Haqqani, Department of Pathology, Walton Hospital, Rice Lane, Liverpool L9 1AE, England. 